\title{
Erratum to: The gift of advice: communication in a bilateral gift exchange game
}

\author{
David J. Cooper · John P. Lightle
}

Published online: 30 July 2013

(C) Economic Science Association 2013

\section{Erratum to: Exp Econ}

DOI 10.1007/s10683-012-9347-3

The gift of advice: communication in a bilateral gift exchange game

- David J. Cooper,

- John P. Lightle

In the original publication, we neglected to acknowledge assistance from NSF grant SES-0924772.

The online version of the original article can be found under doi:10.1007/s10683-012-9347-3.

D.J. Cooper

Department of Economics, Florida State University and School of Economics, University of East Anglia, Norwich, UK

J.P. Lightle (凶)

Department of Economics, Florida State University, Tallahassee, FL 32306-2180, USA

e-mail: jlightle@fsu.edu 